\title{
Cattle prefer endophyte-free robust needlegrass
}

\author{
T.A. JONES, M.H. RALPHS, D.R. GARDNER AND N.J. CHATTERTON
}

First and fourth authors are research geneticist and research plant physiologist, USDA-ARS Forage and Range Research Lab., Utah State University, Logan, Utah 84322-6300. Second and third authors are range scientist and research chemist, USDA-ARS Poisonous Plant Research Lab., Utah State University, Logan, Utah 84322-6300.

\section{Abstract}

Robust needlegrass (Achnatherum robustum [Vasey] Barkw. = Stipa robusta [Vasey] Scribn.) is a high-biomass rangeland species that is adapted to warmer temperatures and matures later than most cool-season grasses. However, it has been associated with negative animal effects including avoidance. We compared populations of Neotyphodium and $P$-endophyte-infected endophyte-infected $(\mathrm{E}+)$ and endophyte-free (E-) robust needlegrass for animal preference. Leaf blades were fed to yearling heifers in 3 trials of 8-min cafeteria sessions for 4 to 5 days each. Trial 1 (27-30 May) compared E+, E-, basin wildrye (Leymus cinereus [Scribn. \& Merr.] A. Löve), and tall wheatgrass (Thinopyrum ponticum [Podp.] Barkw. \& D.R. Dewey). Basin wildrye consumption $(\mathbf{4 2 5} \mathrm{g})$ did not differ from tall wheatgrass ( $342 \mathrm{~g})$, but basin wildrye consumption exceeded $\mathrm{E}-(258 \mathrm{~g})$, which in turn exceeded $E+(117 \mathrm{~g})$ (16 animal-sessions). Basin wildrye was dropped from Trial 2 because its consumption exceeded that of both E- and E+. In Trial 2 (1-5 June), consumption of E-, E+, and tall wheatgrass did not differ. Tall wheatgrass was dropped from Trial 3 to allow direct comparison of $E$ - and E+. In Trial 3 (13-17 July), consumption of E- (585 g) exceeded E+ (145 g) (15 animal-sessions). In Trial 3, animals often rejected $\mathrm{E}+$ forage before tasting. Discrimination against $\mathrm{E}+$ was greater at the end of Trial 3 than at the beginning. The reputation of robust needlegrass for animal avoidance may be more related to its endophyte infection status than to the grass itself. Differences in forage-quality parameters were not large enough to account for the observed differences in preference. Ergot and loline alkaloids were not found in either $\mathbf{E}$ - or $\mathbf{E}+$, therefore they cannot be responsible for the observed avoidance of $E+$. Non-trace amounts of ergot alkaloids were found only in seed collected in the Sacramento Mountains of New Mexico and not at other locations in New Mexico, Arizona, or Colorado.

Key Words: Achnatherum robustum, Acremonium, ergonovine, lysergic acid amide, narcosis, Neotyphodium, sleepygrass, Stipa robusta

This research was supported by the Utah Agricultural Experiment Station, Utah State University, Logan, Utah 84322-4810. Approved as journal paper no. 7100. Capable technical assistance provided by Terrie Wierenga, Dale Nielson, Phil Harrison, Derek Hinckley, and Susan Kenzle is greatly appreciated. Donations of lysergic acid amide by Richard A. Shelby (Dept. of Plant Pathology, Auburn University) and tall fescue seed (Timothy D. Phillips, Dept. of Agronomy, University of Kentucky) for recognition of loline alkaloids are gratefully acknowledged. Thanks are also extended to Susan Durham for statistical guidance.

Manuscript accepted 11 Nov. 1999.

\section{Resumen}

"Robust needlegrass"(Achnatherum robustum [Vasey] Barkw. = Stipa robusta $[$ Vasey] Scribn.) es una especie de pastizal de alta producción de biomasa adaptada a temperaturas calientes y que madura mas tarde que la mayoría de los zacates de época fría. Sin embargo, esta especie se ha asociado con efectos negativos del animal incluyendo el rechazo. Comparamos la preferencia animal en poblaciones de "Robust needlegrass" libres de endófitos (E-) e infectadas con endófitos (Neotyphodium y Phialophora) $(\mathrm{E}+)$. Vaquillas de año se alimentaron con láminas de la hoja del zacate en tres experimentos tipo cafetería de 8 minutos de duración durante un período de 4 a 5 días cada ensayo. En el ensayo 1 ( 27 al 30 de Mayo) comparamos E+, E-, "basin wildrye" (Leymus cinerus [Scribn. \& Merr.] A. L've) y "Tall wheatgrass" (Thinopyrum ponticum [Podp.] Barkw. \& D.R. Dewey). El consumo de "Basin wildrye" (425 g) no difirió del de "Tall wheatgrass" (342 g), pero el consumo de "Basin wildrye" superó al de E- $(258 \mathrm{~g})$ el cual a su vez fue mayor que el de E+ (117 g) (16 sesiones-animal). El "Basin wildrye" se elimino del ensayo 2 porque su consumo superó el de E- y E+. En el ensayo 2 (1-5 de Junio), el consumo de E-, E+ y "Tall wheatgrass" no difirió. "Tall wheatgrass" se elimino en el ensayo 3 para permitir una comparación directa del consumo de E- y E+. En el experimento 3 (13-17 Julio), el consumo de $\mathrm{E}$ - (585 g) fue mayor que el de $E+(145 \mathrm{~g})$ (15 sesiones-animal). En el ensayo 3, los animales a menudo rechazaron el forraje de $\mathrm{E}+$ antes de probarlo. La discriminación contra $E+$ fue mayor al final del ensayo 3 que al principio. La reputación del "Robust needlegrass" de ser evitado por el ganado puede estar mas relacionado a su estado de infección endófita que al zacate por si mismo. Las diferencias en los parámetros de calidad de forraje no fueron lo suficientemente grandes para atribuirles la diferencias de preferencia observadas durante los experimentos. Los alcaloides Ergot y Leolina no se encontraron ni en E- ni en E+, por lo tanto ellos no pueden ser responsables del rechazo observado hacia el E+. Solo en la semilla colectada en Sacramento se encontraron cantidades no traza del alcaloides Ergot.

Robust needlegrass (Achnatherum robustum [Vasey] Barkw.) has long been known to deleteriously affect horses by inducing a narcosis characterized by deep sleep (Bailey 1903). Although this grass is notorious for its narcotic properties, this effect appears to be occasional. Narcosis has only been reported in Lincoln and Otero counties (Sacramento Mountains) in southern New Mexico and not in other parts of the state (Wooton and Standley 1912). Neither has narcosis of horses been reported in Arizona, Colorado, Montana, or Wyoming, all states where the grass is found. 
When fed robust needlegrass from Otero County, sheep exhibited elevated body temperature, depression, weakness in the legs, and mucous intestinal discharge, but not narcosis (Marsh and Clawson 1929). No symptoms were detected in cattle in this study, but later workers reported cattle grazing in Otero County assumed a recumbent position, urinated frequently, and slobbered excessively (Smalley and Crookshank 1976). Grass from 3 northern New Mexico locations did not induce symptoms in horses, sheep, or cattle.

Cattle familiar with robust needlegrass sites have been reported as avoiding this grass assiduously (Bailey 1903), though this may not be true on all sites. This avoidance is the primary economic impact, not infrequent narcosis.

White (1987) was first to report the Neotyphodium endophyte, formerly Acremonium (Glenn et al. 1996), in robust needlegrass. Lysergic acid amide was the dominant alkaloid in Neotyphodiuminfected robust needlegrass forage collected in Otero County (Petroski et al. 1992). Other alkaloids detected were isolysergic acid amide, 8-hydroxylysergic acid amide, ergonovine, chanoclavine-1, and $\mathrm{N}$ formylloline. We suspect that the endophyte or its associated alkaloids may be responsible for avoidance of robust needlegrass, based on findings with other grasses (Garner and Cornell 1987, Fribourg et al. 1991, Miles et al. 1996).

Kaiser et al. (1996) isolated Neotyphodium from robust needlegrass seed collected from 10 New Mexico and Colorado populations. Fungal isolates were notable for their diversity of spore morphology. Serological diversity, as determined by western blot analysis, was greater than expected for a single host species. Diversity was more similar to that seen among endophytes from a wide variety of hosts. The observation of diversity within the A. robustum endophyte, the general presence of the endophyte throughout the host's range (Kaiser et al. 1996), and the restriction of somnolence symptomology to Lincoln and Otero counties (Wooten and Standley 1912) imply that most endophyte strains are not associated with narcosis.

Our objective was to determine if cattle preferred robust needlegrass accession $\mathrm{T}$ 953 (Cokedale, Colo.) relative to T-961 (Center, Colo.). We previously determined that T-953 is naturally endophyte-free (E-) while T-961 is endophyte-infected (E+). We also wished to determine if ergot or loline alkaloids were associated with avoidance of $\mathrm{E}+$ robust needlegrass and how widespread ergot alkaloids were in accessions collected in Arizona, Colorado, and New Mexico.

\section{Materials and Methods}

$\mathrm{E}-(\mathrm{T}-953)$ and $\mathrm{E}+(\mathrm{T}-961)$ robust needlegrasses were harvested from seed fields near Richmond, Utah. The T-953 accession was originally collected in a floodplain near the confluence of Burro Creek and the Purgatoire River near Cokedale, Colo. (Las Animas Co.). Associated native species were rabbitbrush (Chrysothamnus sp.), juniper (Juniperus sp.), snakeweed (Gutierrezia sarothrae [Pursh] Britt. \& Rusby), Indian ricegrass (Achnatherum hymenoides [Roem. \& Schult.] Barkw.), and western wheatgrass (Pascopyrum smithii [Rydb.] A. Löve). The T-961 accession was originally collected near Center, Colo. (Saguache Co.). Associated native species were inland saltgrass (Distichlis stricta [Torr.] Rydb.), sand dropseed (Sporobolus cryptandrus [Torr.] A. Gray), Indian ricegrass, and slender wheatgrass (Elymus tra chycaulus [Link] Gould ex Shinners). Tall wheatgrass was harvested from wild stands in Benson, Utah. Basin wildrye originating from eastern Washington and northeastern Oregon was harvested from research plots at Evans Farm near Millville, Utah. To condition the test animals, freshly harvested leaf blades were fed for 4 days before the beginning of Trial 1 (27-30 May, 1998). Trial 2 (1-3 and 5 June, 1998) followed the week after Trial 1. Feeding freshly harvested leaf blades was repeated for 2 days prior to the beginning of Trial 3 (13-17 July, 1998), 6 weeks after the beginning of Trial 2 .

In Trial 1, $600 \mathrm{~g}$ of freshly cut leaf blades of basin wildrye, tall wheatgrass, $\mathrm{E}-$, and $\mathrm{E}+$ were weighed and offered to each of 4 red angus heifers about age 2 in 4 adjacent feeding stations. Forages were rotated among feeding stations daily. Feeding trials were conducted for 4 days. Two heifers evaluated the forages simultaneously in adjacent pens for $8 \mathrm{~min}$. Time spent by each animal consuming each forage was recorded. Orts were weighed and consumption was determined by subtraction. Then the 2 remaining heifers were offered the forages. Heifers were fed a daily ration of alfalfa hay ad lib. immediately following each late morning trial and then fasted overnight until the succeeding trial the following morning.

Forages were offered for 4 days in Trial 2 similarly to Trial 1 except basin wildrye was not included. Forages offered for Trial 3 did not include basin wildrye or tall wheatgrass; only E+ and E- robust needlegrasses were offered. In Trial 3, $500 \mathrm{~g}$ of each forage was offered at each of 2 feeding stations for 5 days. One animal used in Trials 1 and 2 refused to eat in Trial 3; thus data could only be obtained from 3 animals.

Data for each trial were analyzed as a split-plot design with animals as replicates (random effect), days as whole-plots (fixed effect), and forages as split-plots (fixed effect). The day effect was tested with the animal $\mathrm{X}$ day interaction term. The forage and day $\mathrm{X}$ forage effects were tested with error $\mathrm{b}$ (animal $\mathrm{X}$ forage and animal $\mathrm{X}$ day $\mathrm{X}$ forage interaction terms combined) when these terms were homogeneous (Trial 1). When these 2 interaction terms were nonhomogeneous (Trials 2 and 3), the forage effect was tested by the animal $\mathrm{X}$ forage interaction term and the day $\mathrm{X}$ forage interaction was tested by the animal $\mathrm{X}$ day $\mathrm{X}$ forage interaction term. In Trial 3 the day effect was partitioned into linear and residual components. The day (linear) $\mathrm{X}$ forage and residual (lack-of-fit) $\mathrm{X}$ forage effects were tested with the animal $X$ day $X$ forage term to assess changes in preference over the course of the trial. Forage means in Trials 1 and 2 were separated with the Waller-Duncan kratio $t$ test at $\mathrm{k}$-ratio $=100$.

E- and E+ robust needlegrasses were checked for presence of the Neotyphodium and $P$-endophytes in 27 plants each (Siegel et al. 1995). Flowering stems were removed and split lengthwise with a razor blade. Pith tissue was removed from the center of the stem, placed on a microscope slide, and stained with aniline blue lactic acid (Bacon et al. 1977). Individual stems were scored for presence or absence of each of the 2 endophytes (Figs. 1, 2).

Samples of each forage were taken at time of feeding and dried at $60^{\circ} \mathrm{C}$ to determine dry-matter (Trials 1, 2, and 3), aciddetergent fiber, soluble sugars, total nonstructural carbohydrates (TNC), ergot alkaloid (ergonovine and lysergic acid amide), and loline alkaloid (loline, $\mathrm{N}$ methylloline, $\mathrm{N}$-acetylloline, and $\mathrm{N}$ formylloline) concentrations (Trial 3). Trial 3 samples were ground through a 1$\mathrm{mm}$ screen following drying. Acid-detergent fiber was determined according to Goering and Van Soest (1970). Crude protein was calculated as Kjeldahl N X 6.25. Each acid-detergent fiber and crude protein sample was evaluated in duplicate. For soluble sugars, about $20 \mathrm{mg}$ of tissue was extracted for $15 \mathrm{~min}$ at 85 to $90^{\circ} \mathrm{C}$ in 


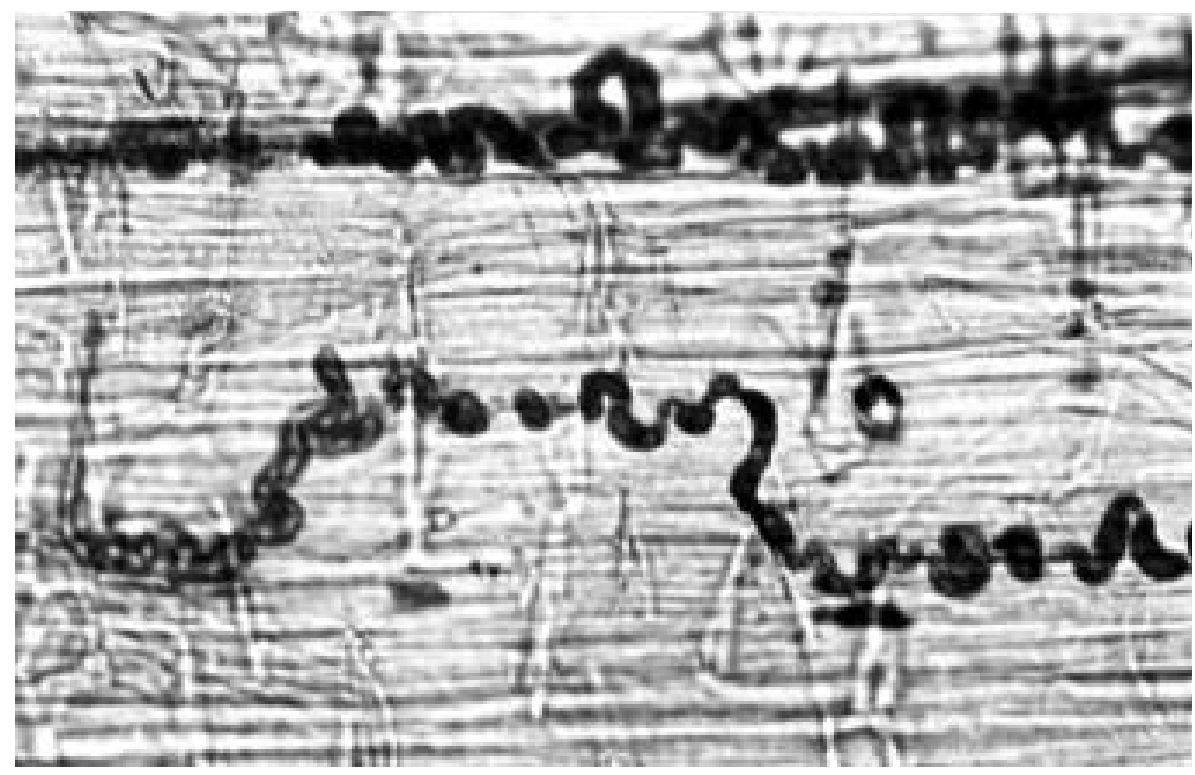

Fig. 1. The Neotyphodium endophyte among pith parenchyma cells in tissue teased from a stem of T-961 robust needlegrass (320X).

3 changes of $2 \mathrm{ml}$ deionized water each. Sugar determination was with the anthrone color reaction method adapted from Pollock (1982). Assays were performed in test tubes at $85^{\circ} \mathrm{C}$ for 1 hour. At this temperature, both furanoses, e.g., fructose, and pyranoses, e.g., glucose, react. Aliquots of the finished reaction were transferred to a microplate and read at $620 \mathrm{~nm}$. For TNC determination, an additional $20 \mathrm{mg}$ of tissue was heated with $2 \mathrm{ml}$ deionized water for $15 \mathrm{~min}$. After cooling, $4 \mathrm{ml}$ of $0.2 \%$ Clarase $^{1}$ (amylase) was added to each sample and enzymatic digestion was allowed to proceed for 24 hours to digest starch. Anthrone assay was then performed as on the water extract for soluble sugar determination. Soluble sugar and TNC determinations were not duplicated. Dry-matter, acid-detergent fiber, crude protein, soluble sugars, and TNC concentrations of grasses were compared using a randomized complete block design with days as replications (random effect). Means in Trials 1 and 2 were separated with the Waller-Duncan k-ratio t test at kratio $=100$

Samples for ergot alkaloid analysis were prepared by adding $4 \mathrm{ml}$ alkaline methanol and $1 \mathrm{ml}$ internal standard (20 $\mu \mathrm{g}$ ergotamine tartrate in $1.0 \mathrm{ml}$ methanol) to $100 \mathrm{mg}$ ground plant tissue. The samples were rotated overnight and filtered. The filtrate was dried at $60^{\circ} \mathrm{C}$ over a

\footnotetext{
${ }^{1}$ Mention of a proprietary product does not constitute a guarantee or warranty by USDA or the Utah Agric. Exp. Stn. and does not imply its approval to the exclusion of other products that may also be suitable.
}

stream of $\mathrm{N}_{2}$ and reconstituted with $1 \mathrm{ml}$ methanol. Reversed-phase high-performance liquid chromatography was performed using an $\mathrm{HP}^{1} 1090$ HPLC equipped with a Beckman ${ }^{1} \mathrm{C} 18$ silica endophyte from Neotyphodium (upper right). (ultrasphere) column $(4.6 \times 250 \mathrm{~mm})$ and $\mathrm{HP}^{1} 1040$ fluorescence detector. Fluorescence emission was measured at $420 \mathrm{~nm}$ with excitation at $310 \mathrm{~nm}$. Chromatographic conditions were as follows: mobile phase; (A) water $+0.1 \%$ ammonium acetate, and (B) acetonitrile. Flow rate was $1 \mathrm{ml} \mathrm{min}^{-1}$ in a linear gradient from $10 \%$ B to $40 \% \mathrm{~B}, 0-15 \mathrm{~min} ; 40 \%$ $\mathrm{B}$ to $100 \% \mathrm{~B}, 15-25 \mathrm{~min}$. For loline alkaloid detection, a $100 \mathrm{mg}$ aliquot of the dry ground plant material was extracted with a mixture of $4 \mathrm{ml} \mathrm{CHCl}_{3}$ and $4 \mathrm{ml} 1 \%$ $\mathrm{H}_{2} \mathrm{SO}_{4}$ for 1 hour. The sample was centrifuged to aid layer separation and the aqueous portion was removed and saved. The sample was extracted a second time with $2 \mathrm{ml}$ of $1 \% \mathrm{H}_{2} \mathrm{SO}_{4}$ for $5 \mathrm{~min}$ and centrifuged. The acidic aqueous portion was removed and combined with the first acid extract. The acid solution was made basic $(\mathrm{pH}=9)$ by the addition of concentrated $\mathrm{NH}_{4} \mathrm{OH}$ and the sample extracted twice with $\mathrm{CHCl}_{3}(4 \mathrm{ml}, 2 \mathrm{ml})$. The $\mathrm{CHCl}_{3}$ extracts were combined and filtered through anhydrous $\mathrm{Na}_{2} \mathrm{SO}_{4}$ and concentrated to $1 \mathrm{ml}$.

Loline alkaloids were analzyed by gas chromatography/mass spectrometry using

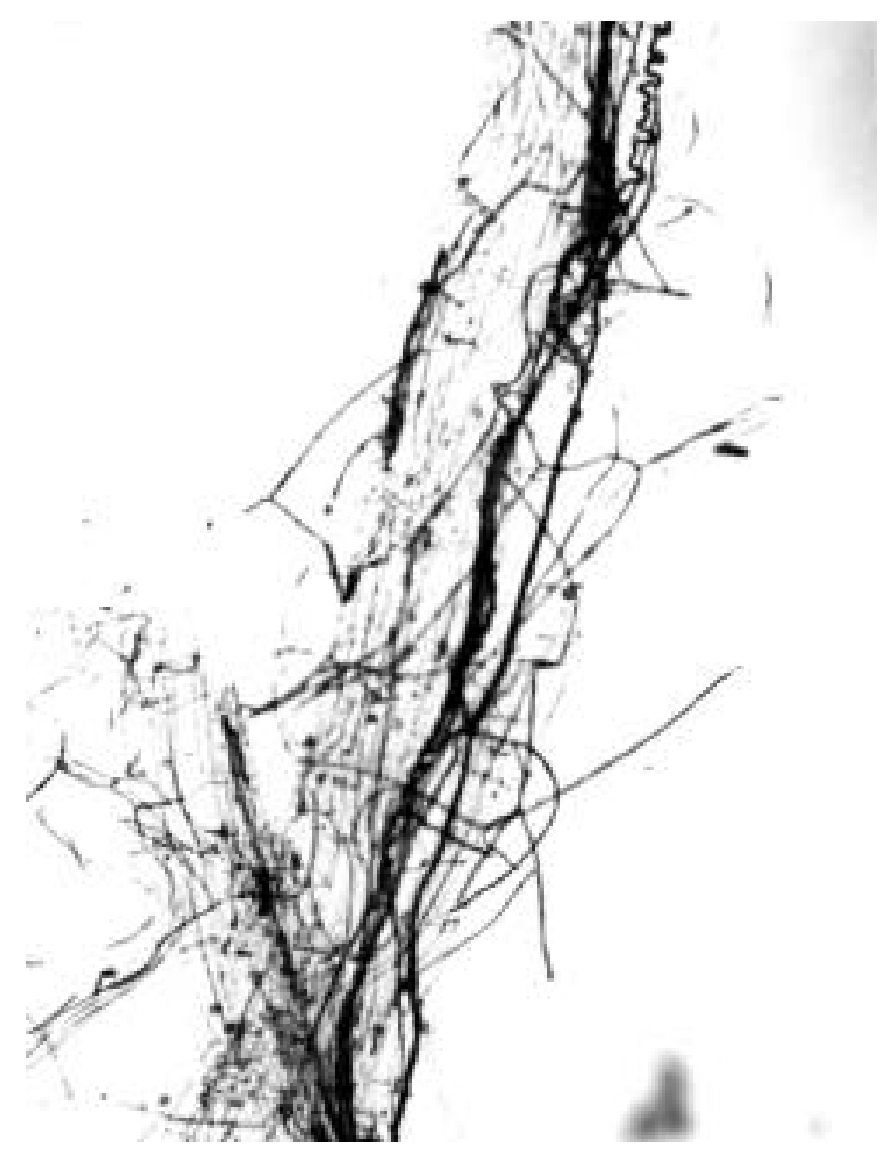

Fig. 2. The $P$-endophyte in T-961 robust needlegrass $(80 \mathrm{X})$. Branching hyphae distinguish the $\boldsymbol{P}$ - 
a Finnigan ${ }^{1}$ GCQ. The GC conditions were as follows: column was a DB-5ms (30 m x $0.25 \mathrm{~mm}$ i.d., J\&W Scientific ${ }^{1}$ ); injector temperature $=225^{\circ} \mathrm{C}$; oven temperature $=$ initial $80^{\circ} \mathrm{C}$ for $1.0 \mathrm{~min}, 80-250$ @ $10^{\circ} \mathrm{C} / \mathrm{min}$, final $250^{\circ} \mathrm{C}$ for $5 \mathrm{~min}$. The heated transfer line was $275^{\circ} \mathrm{C}$ and the ion source was $150^{\circ} \mathrm{C}$. Electron impact $(70 \mathrm{eV})$ spectra were recorded for the mass range $60-400 \mathrm{~m} / \mathrm{z}$ at a scan rate rate of 0.5 sec/scan. Positive loline detection was confirmed by the analysis of a standard sample of 'Kentucky 31' tall fescue seed.

\section{Results and Discussion}

E- and E+ robust needlegrass populations were collected as seed in 1993 and established as transplants near Richmond, Utah in April 1996, after an initial seed increase. Cytological examination for the endophytes in the fields near Richmond revealed a small amount of infection with the Neotyphodium endophyte in 1 stem of E-, while the 26 remaining stems were Neotyphodium-free. No P-endophyte mycelium was found in E-. In contrast, the Neotyphodium endophyte was found in 26 of 27 stems of E+, with 25 of the 26 also infected with the $P$-endophyte. No infection of either endophyte was found in 1 stem. The $P$-endophyte mycelium was considerably less concentrated in the pith tissue than the Neotyphodium endophyte in E+. This is the first report of the $P$ endophyte in robust needlegrass.

In Trial 1, consumption and time spent feeding were greater for basin wildrye

Table 1. Consumption and time ( $s=$ seconds) spent feeding by cattle of leaf blades of basin wildrye, tall wheatgrass, and T-953 (E-) and T-961 (E+) robust needlegrasses in 3 trials.

\begin{tabular}{lcc}
\hline \hline Forage & Consumption & Time \\
\hline Trial 1 & & \\
\hline basin wildrye & $\left(\right.$ g day $\left.^{-1}\right)$--------- & \\
tall wheatgrass & $425 \mathrm{a}^{1}$ & $187 \mathrm{a}$ \\
E- robust needlegrass & $342 \mathrm{ab}$ & $121 \mathrm{~b}$ \\
E+ robust needlegrass & $258 \mathrm{~b}$ & $99 \mathrm{bc}$ \\
SE $\mathrm{X}$ & $117 \mathrm{c}$ & $47 \mathrm{c}$ \\
Trial 2 & 48 & 21 \\
tall wheatgrass & & \\
E- robust needlegrass & 384 & 148 \\
E+ robust needlegrass & 400 & 175 \\
SE $\bar{x}$ & $272 \mathrm{NS}$ & $135 \mathrm{NS}$ \\
Trial 3 & 70 & 31 \\
E- robust needlegrass & & 366 \\
E+ robust needlegrass & 585 & $91 \dagger$ \\
SE $\frac{\mathrm{X}}{}$ & $145 \dagger$ & 57 \\
\hline
\end{tabular}

${ }^{\mathrm{M}}$ Means followed by different letters within a column and trial are different according to the Waller-Duncan k-ratio $\mathrm{t}$ test $(\mathrm{k}$-ratio $=100)$.

$\dagger$ Significantly different $(\mathrm{P}<0.10)$. $=100$.

**Significantly different $(\mathrm{P}<0.01)$

Table 2. Dry-matter concentrations of basin wildrye, tall wheatgrass, and T-953 (E-) and T-961 $(\mathrm{E}+)$ robust needlegrass leaf blades fed to cattle in 3 trials.

\begin{tabular}{lccc}
\hline \hline Forage & Trial 1 & Trial 2 & Trial 3 \\
\hline & & Dry matter & \\
basin wildrye & $290 \mathrm{a}^{1}$ & - & - \\
tall wheatgrass & $271 \mathrm{a}$ & $284 \mathrm{a}$ & - \\
E- robust needlegrass & $405 \mathrm{~b}$ & $410 \mathrm{~b}$ & 461 \\
E+ robust needlegrass & $389 \mathrm{~b}$ & $394 \mathrm{~b}$ & $435^{* *}$ \\
$\mathrm{SE} \times$ & 7 & 6 & 2 \\
\hline
\end{tabular}

than either robust needlegrass (Table 1). Cattle use of tall wheatgrass was similar to E- for these variables but greater than E+. Consumption and time spent feeding of Ewas about twice that of E+. To provide a more succinct comparison of the robust needlegrasses and tall wheatgrass, basin wildrye was not included in Trial 2 the following week. Basin wildrye was deleted from Trial 2 because it differed from Efor both consumption and time spent feeding, while tall wheatgrass and E+ did not. However, no differences $(\mathrm{P}>0.10)$ among grasses were found for either variable in Trial 2.

Trial 3 was conducted to directly compare E- and E+. Ranchers we interviewed reported that animals accept robust needlegrass early in the growing season but reject it as it matures. Therefore, we delayed Trial 3 for 6 weeks to augment any differences that might be present. Consumption and time spent feeding Ewere 4 times greater than $\mathrm{E}+$, a difference $(P<0.10)$ much greater than in Trials 1 or other. At the same time, consumption of tall wheatgrass was similar to E-, but Econsumption was greater than E+. Drymatter concentration in Trial 2 was similar to that of Trial 1 the preceding week. In Trial 3, dry-matter concentration was 41$51 \mathrm{~g} \mathrm{~kg}^{-1}$ greater than Trial 2, 6 weeks before. The preferred forage, E-, was higher in dry-matter concentration than $\mathrm{E}+$.

We found no difference $(P>0.10)$ in leaf blade acid-detergent fiber between $\mathrm{E}$ (343 $\left.\mathrm{g} \mathrm{kg}^{-1}\right)$ and $\mathrm{E}+\left(344 \mathrm{~g} \mathrm{~kg}^{-1}\right)$ robust needlegrasses or among the 5 days of Trial 3 . We found a small difference $(\mathrm{P}<0.10)$ in crude protein between E- $\left(143 \mathrm{~g} \mathrm{~kg}^{-1}\right)$ and $\mathrm{E}+\left(133 \mathrm{~g} \mathrm{~kg}^{-1}\right)$ robust needlegrasses, but no difference among the 5 days of Trial 3. We found a small difference $(\mathrm{P}<$ $0.05)$ in soluble sugars between E- (45 g 
$\left.\mathrm{kg}^{-1}\right)$ and $\mathrm{E}+\left(43 \mathrm{~g} \mathrm{~kg}^{-1}\right)$, with a $7 \mathrm{~g} \mathrm{~kg}^{-1}$ difference between the highest (day 1) and lowest (day 2) days of Trial 3. Concentrations of TNC were slightly different $(\mathrm{P}<0.10)$ between E- $(45 \mathrm{~g} / \mathrm{kg})$ and $\mathrm{E}+\left(42 \mathrm{~g} \mathrm{~kg}^{-1}\right)$ with no differences among the 5 days of Trial 3. The similarity of soluble sugars and TNC indicates that starch concentration was negligible.

The 4-fold preference of E- in Trial 3 could not be attributed to any measure of forage quality. Ergonovine and lysergic acid amide were not detected in E- or E+ robust needlegrasses in Trial 3. Therefore, the ergot alkaloids are not primarily responsible for avoidance of $\mathrm{E}+$, as has been proposed for narcosis (Petroski et al. 1992). Neither were loline alkaloids found in E- or E+ robust needlegrasses. Some other chemical constituent or physical property associated with the endophytes must be responsible for differences in preference.

Although narcotic potential beyond the Sacramento Mountain area is probable, it is likely infrequent. Of 54 accessions of seed collected during 1995 in Colorado, New Mexico, and Arizona, we found measurable quantities of ergonovine and lysergic acid present at only 6 sites, all in Otero County, N.M. Trace levels were found in 1 collection from Apache Co., Ariz. between Springerville, Ariz. and Luna, N.M. Because lysergic acid amide has a sedative effect and is the dominant alkaloid in whole-plant samples, Petroski et al. (1992) suggested that it is the causative agent for narcosis. Our biogeographical data lend support to their hypothesis.

The Neotyphodium endophyte in tall fescue has also been associated with avoidance in cattle. Steers preferred clover in mixed $\mathrm{E}+$ tall fescue (Festuca arundi nacea Schreb.)/white clover (Trifolium repens L.) pastures, but they preferred Etall fescue in mixed E- tall fescue/white clover pastures (Fribourg et al. 1991). Eleven of 12 heifers avoided diets with $60 \% \mathrm{E}+$ tall fescue seed in favor of diets with $60 \%$ E- tall fescue seed (Garner and Cornell 1987).

\section{Management Implications}

Based on our results, E- robust needlegrass may provide desirable forage, particularly in areas in the transition zone between cool- and warm-season grasslands. The grass produces abundant forage later in the growing season than other cool-season grasses. Because of its very late maturity, robust needlegrass leaf-to- stem ratio remains high during June, July, and early August. Thus, robust needlegrass may provide palatable forage at the time of year when other cool-season grasses are heading and senescing. Robust needlegrass produces coarse stems with few leaves once it begins to head, but grazing may delay the appearance of heads. We have observed rapid leaf regrowth from cut tillers in the field.

Concomitantly, E+ robust needlegrass may provide a deterrent to grazing where it is not desired, e.g., in riparian areas and along roadsides. Height may limit the use of this grass along roadsides. We are currently evaluating accessions for shortness and late heading for such an application. Robust needlegrass may be particularly effective in deterring roadkill of deer because of its late green-up in spring. Early spring is the only time of year when deer utilize significant amounts of grass. If green grass is not present at this time of year along roadsides, vehicular collisions with deer could be reduced.

\section{Literature Cited}

Bacon, C.W., J.K. Porter, J.D. Robbins, and E.S. Luttrell. 1977. Epichloë typhina from toxic tall fescue grasses. Appl. Environ. Microbiol. 34:576-581.

Bailey, V. 1903. Sleepy grass and its effect on horses. Sci. 17:392-393.

Fribourg, H.A., A.B. Chestnut, R.W. Thompson, J.B. McLaren, R.J. Carlisle, K.D. Gwinn, M.C. Dixon, and M.C. Smith. 1991. Steer performance in fescue clover pastures with different levels of endophyte infestation. Agron. J. 83:777-781.

Garner, G.B. and C.N. Cornell. 1987. University of Missouri report on fescue research activities (Preliminary Report). Proc. Tall Fescue Toxicosis Workshop, Memphis, Tenn.

Glenn, A.E., C.W. Bacon, R. Price, and R.T. Hanlin. 1996. Molecular phylogeny of Acremonium and its taxonomic implications. Mycologia 88:369-383.

Goering, H.K. and P.J. Van Soest. 1970. Forage fiber analysis. ARS-USDA Agr. Handb. 379.

Kaiser, W.J., G.W. Bruehl, C.M. Davitt, and R.E. Klein. 1996. Acremonium isolates from Stipa robusta. Mycologia 88:539-547.

Marsh, C.D. and A.B. Clawson. 1929. Sleepy grass (Stipa vaseyi) as a stock-poisoning plant. USDA Tech. Bull. No. 114.

Miles, C.O., G.A. Lane, M.E. di Menna, I. Garthwaite, E.L. Piper, O. J.-P. Ball, G.C. M. Latch, J.M. Allen, M.B. Hunt, L.P. Bush, K.M. Feng, I. Fletcher, and P.S. Harris. 1996. High levels of ergonovine and lysergic acid amide in toxic Achnatherum inebrians accompany infection by an Acremonium-like endophytic fungus. J. Agr. Food Chem. 44:1285-1290.
Petroski, R.J., R.G. Powell, and K. Clay. 1992. Alkaloids of Stipa robusta (sleepygrass) infected with an Acremonium endophyte. Natural Toxins 1:84-88.

Pollock, C.J. 1982. Patterns of turnover of fructans in leaves of Dactylis glomerata $\mathrm{L}$. New Phytol. 90:645-650.

Siegel, M.R., C.L. Schardl, and T.D. Phillips. 1995. Incidence and compatibility of nonclavicipitaceous fungal endophytes in Festuca and Lolium grass species. Mycologia 87:196-202.

Smalley, H.E., and H.R. Crookshank. 1976. Toxicity studies on sleepy grass, Stipa robus ta (Vasey) Scribn. Southwest. Vet. 29:35-39.

White, J.F., Jr. 1987. Widespread distribution of endophytes in the Poaceae. Plant Disease 71:340-342.

Wooton, E.O., and P.C. Standley. 1912. The grasses and grass-like plants of New Mexico. New Mexico Agric. Exp. Sta. Bull. 81. 